
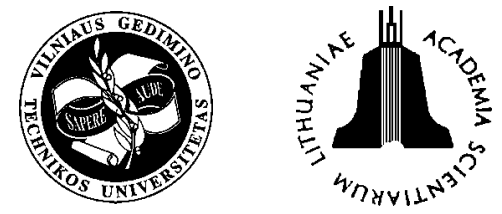

JOURNAL OF CIVIL ENGINEERING AND MANAGEMENT

http:/www.vtu.lt/english/editions

2004, Vol X, No 1, 31-36

\title{
IDENTIFICATION OF PHENOMENA OCCURRING IN POROUS STRUCTURE OF CEMENT CONCRETE SUBJECTED TO CYCLIC FREEZING AND THAWING
}

\author{
Malgorzata Lelusz ${ }^{1}$, Dorota Malaszkiewicz ${ }^{2}$ \\ Faculty of Civil Engineering and Environmental Engineering, Biatystok Technical University, \\ ul. Wiejska 45 E, 15-351Biatystok, Poland. \\ E-mail:11M.Lelusz@kmb.pb.bialystok.pl; 2 dorotam@pb.bialystok.pl
}

Received 17 Sept 2003; accepted 3 Feb 2004

\begin{abstract}
The influence of cyclic freezing and thawing of concrete upon its microstructure is investigated in this research. The following methods were applied: microscope analysis of specially prepared fragments of concrete specimens, capillary pulling up water under atmospheric pressure, thermal analysis of hardened cement paste separated from concrete specimens. Tested concrete did not contain any chemical or mineral admixtures; W/C ratio was constant for all specimens $(0,65)$. Indexes of mean radius of capillary pores $-\lambda$ and indexes of homogeneity of capillary pores $-\alpha$ were measured after various numbers of freezing cycles. Experimental results enable to describe the phenomena occurring in concrete subjected to frost.
\end{abstract}

Keywords: concrete, concrete structure, concrete freeze resistance, cement hydration, products of hydration, SEM analysis, thermal analysis.

\section{Introduction}

The problem of durability of concrete structures is often investigated by researchers from all over the world [1-4]. The scale of losses and costs of repairs indicates the urgent necessity of solving this problem. There is a deep interest in the predicting durability of concrete structures under frost attack [5-8]. Different frost damage models of concrete have been developed in the past by several authors $[9,10]$. Though the deterioration of concrete structure under frost attack has already been described to a certain extent, a deeper understanding of this process, especially for predicting frost resistance, is still necessary. Under microscopic examination cement paste is a non-homogeneous and anisotropic matrix composed of irregularly shaped and unevenly distributed pores. Recognition of phenomena occurring in concrete structure subjected to cyclic freezing and thawing would allow understanding the mechanisms of concrete destruction. Research in this field has been conducted in Bialystok Technical University for several years [11-13]. The present study is focused on recognition and analysis of phenomena occurring in porous structure of cement concrete subjected to cyclic freezing and thawing. A quick method of forecasting concrete freeze resistance on the basis of intensity (speed) of changes of selected porosity parameters after initial cycles of freezing and thawing can be developed.

\section{Characteristics of materials}

River sand was used as a fine aggregate and gravel of fractions $2 \div 4$ and $4 \div 8$ as a coarse aggregate. Grainsize distribution was determined on the basis of recommended graining [14] (sand - 39,2\%; fraction $2 \div 4$ $25,3 \%$; fraction $4 \div 8-35,5 \%$ ). Ordinary Portland cement CEM I 32,5 was used in the experimental research. Properties of this cement are presented in Table 1.

The following concrete composition was used: cement - $300 \mathrm{~kg} / \mathrm{m}^{3}$, water - $195 \mathrm{dm}^{3} / \mathrm{m}^{3}$, sand $717 \mathrm{~kg} / \mathrm{m}^{3}$, gravel $2 \div 4 \mathrm{~mm}-463 \mathrm{~kg} / \mathrm{m}^{3}$, gravel $4 \div 8 \mathrm{~mm}$ $-650 \mathrm{~kg} / \mathrm{m}^{3}$, water-cement ratio $\mathrm{W} / \mathrm{C}=0,65$. Specimens were taken out from moulds after 24 hours and than kept in water for 27 days.

\section{Experimental results}

Examinations of concrete structure were conducted after different number of cycles of freezing and thawing (up to 100 cycles) in order to identify changes in porous concrete structure (DTG, DTA and TG).

The following methods were applied: microscope analysis of selected and specially prepared fragments of concrete specimens using scanning electron microscope, examinations of changes of capillary porosity parameters using capillary pulling up water under atmospheric pressure and thermal analysis. 
Table 1. Mineral composition and properties of cement CEM I 32.5

\begin{tabular}{c|r}
\hline Mineral composition: $\mathrm{C}_{3} \mathrm{~S}$ & $58,09 \%$ \\
$\mathrm{C}_{2} \mathrm{~S}$ & $21,02 \%$ \\
$\mathrm{C}_{3} \mathrm{~A}$ & $12,16 \%$ \\
$\mathrm{C}_{4} \mathrm{AF}$ & $6,20 \%$ \\
Other minerals & $2,53 \%$ \\
\hline Compressive strength after 28 days of hardening & $45 \mathrm{MPa}$ \\
(according to PN-EN 196-1) & $152 \mathrm{ml}$ \\
\hline Water requirement for normal consistency (according to PN-EN 196-1) & \\
\hline Setting times (according to PN-EN 196-3) & 180 minutes \\
- initial setting time & 280 minutes \\
\hline
\end{tabular}

\subsection{Microscope examinations}

SEM examinations were conducted in order to compare morphology of cement hydration products located inside the pores and elements of structure of hardened cement paste of tested concrete specimens. Fragments of surface parts of concrete specimens in the form of fracture of area about $300 \mathrm{~mm}^{2}$ were examined. Magnification was in the range from 20 to $4000 x$.

Air pores were mostly in clusters of few items in tested concrete fragments. The fractions of these pores were circular, diameters in the range from 50 to $100 \mu \mathrm{m}$. Pores of diameter $100 \mu \mathrm{m}$ dominated in all specimens. That is why these pores were subjected to detailed quality observations under SEM and photography documentation was made. Four series of concrete specimens were examined. All specimens were kept in water until the $28^{\text {th }}$ day of hardening and than they were subjected to different number of cycles of freezing and thawing. One series of specimens - control one was kept in water.

\section{Specimens not subjected to frost}

Very fine hydrated calcium silicates C-S-H and relicts of unhydrated cement can be recognised in cement stone microstructure. Air pores of various diameters are concentrated in clusters of few items. Some of them are cracked inside and they are filled with products of hydration to a small degree. Typical structure is presented in Fig 1.
Specimens after 25 cycles of freezing and thawing

Hydrated calcium silicates C-S-H and relicts of unhydrated cement can be recognised in hardened cement paste microstructure. There are not many air pores in these specimens; they are relatively shallow and filled with newly created products of cement hydration. Each of examined pores has microcracks. Typical images of these specimens are presented in Figs 2 and 3.

\section{Specimens after 75 cycles of freezing and thawing}

Very fine hydrated calcium silicates $\mathrm{CSH}$, crystals of ettringite and relicts of unhydraed clinker can be recognized in cement stone microstructure. Air pores, like in the previous specimens, were in clusters of few items. Pores are filled by products of cement hydration. Deeper pores are less filled by products of hydration. Typical images of concrete specimens are presented in Figs 4 and 5 .

Specimens after 100 cycles of freezing and thawing

Very fine hydrated calcium silicates $\mathrm{CSH}$, crystals of ettringite and relicts of unhydraed clinker can be recognised in cement stone microstructure. The biggest number of air pores was observed in this specimen. These pores are filled by product of hydration to various extents. Bigger pores are less filled and smaller ones are completely filled by products of hydration. Typical images of concrete specimens are presented in Figs 6, 7 and 8 .

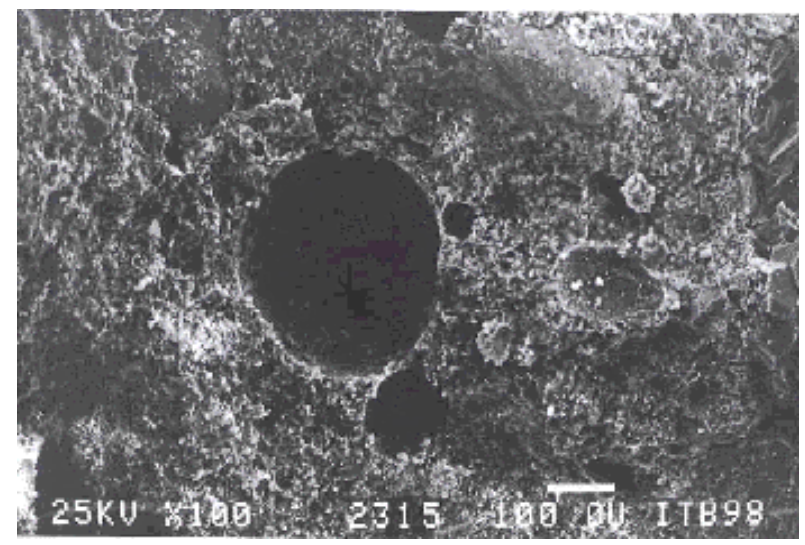

Fig 1. Fraction of concrete specimen; 0 cycles of freezing and thawing; SEM: magnification 100x 


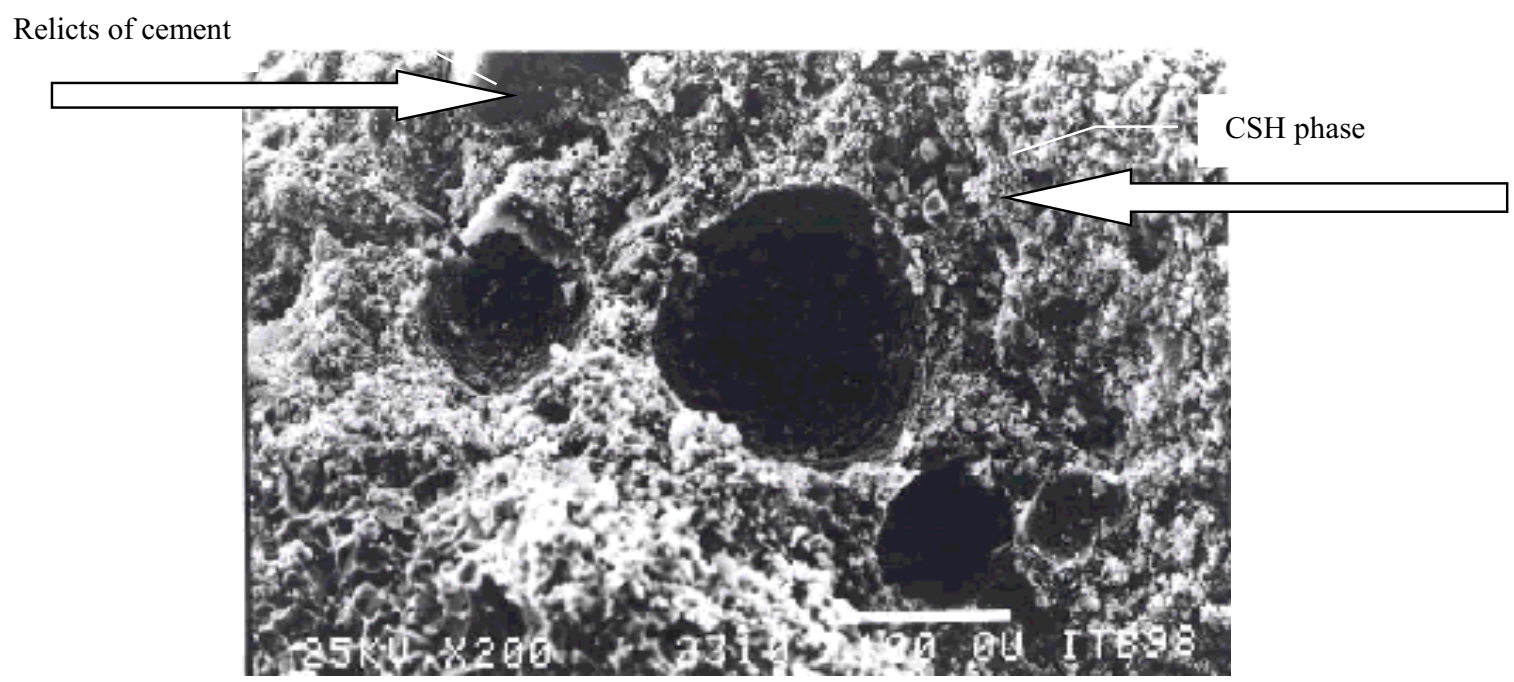

Fig 2. Fraction of concrete specimen after 25 cycles; SEM: magnification $200 x$

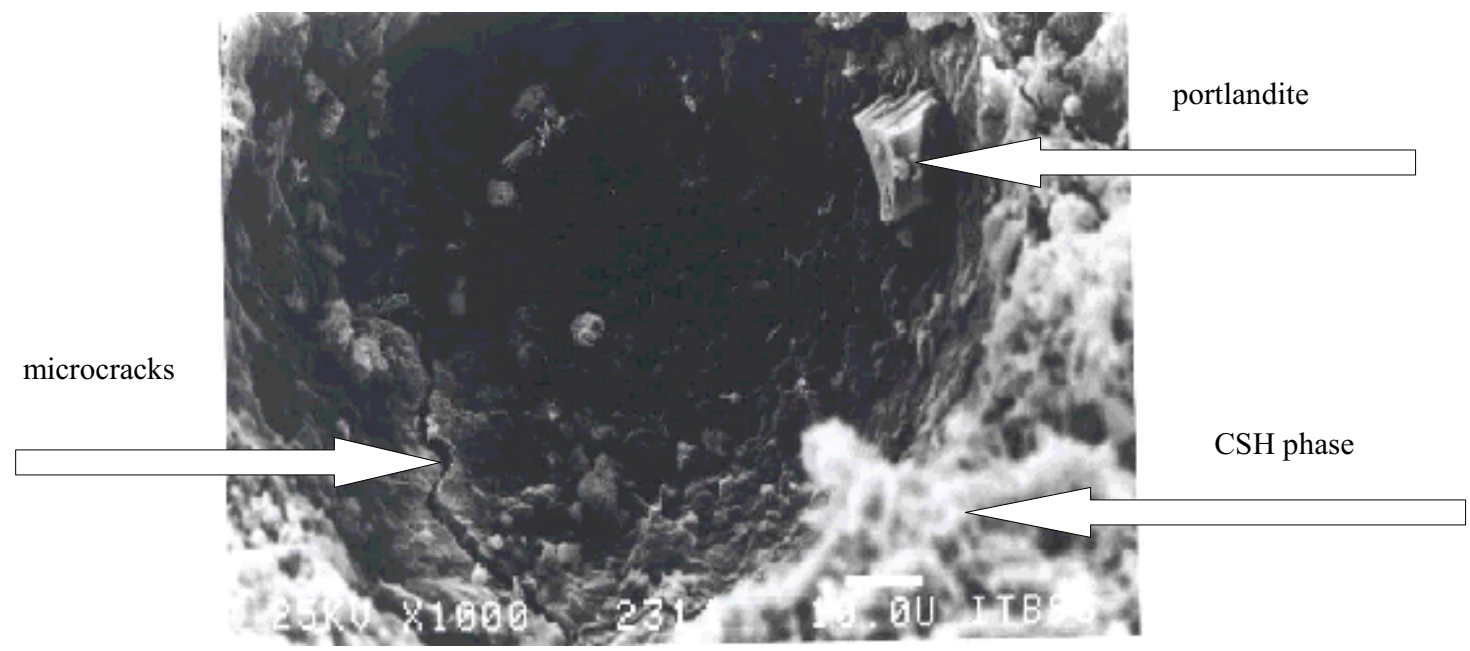

Fig 3. Fraction of concrete specimen after 25 cycles; SEM: magnification 1000x

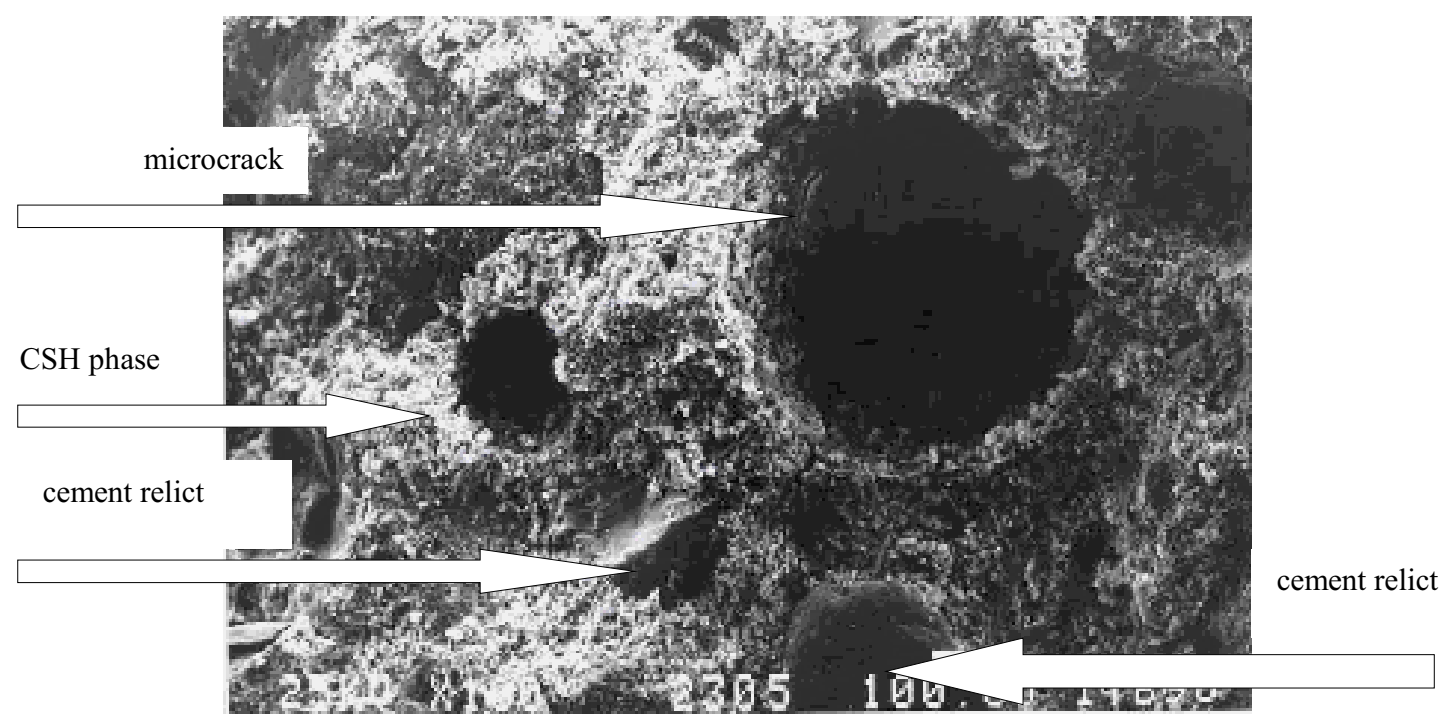

Fig 4. Fraction of concrete after 75 cycles; SEM: magnification 100x 


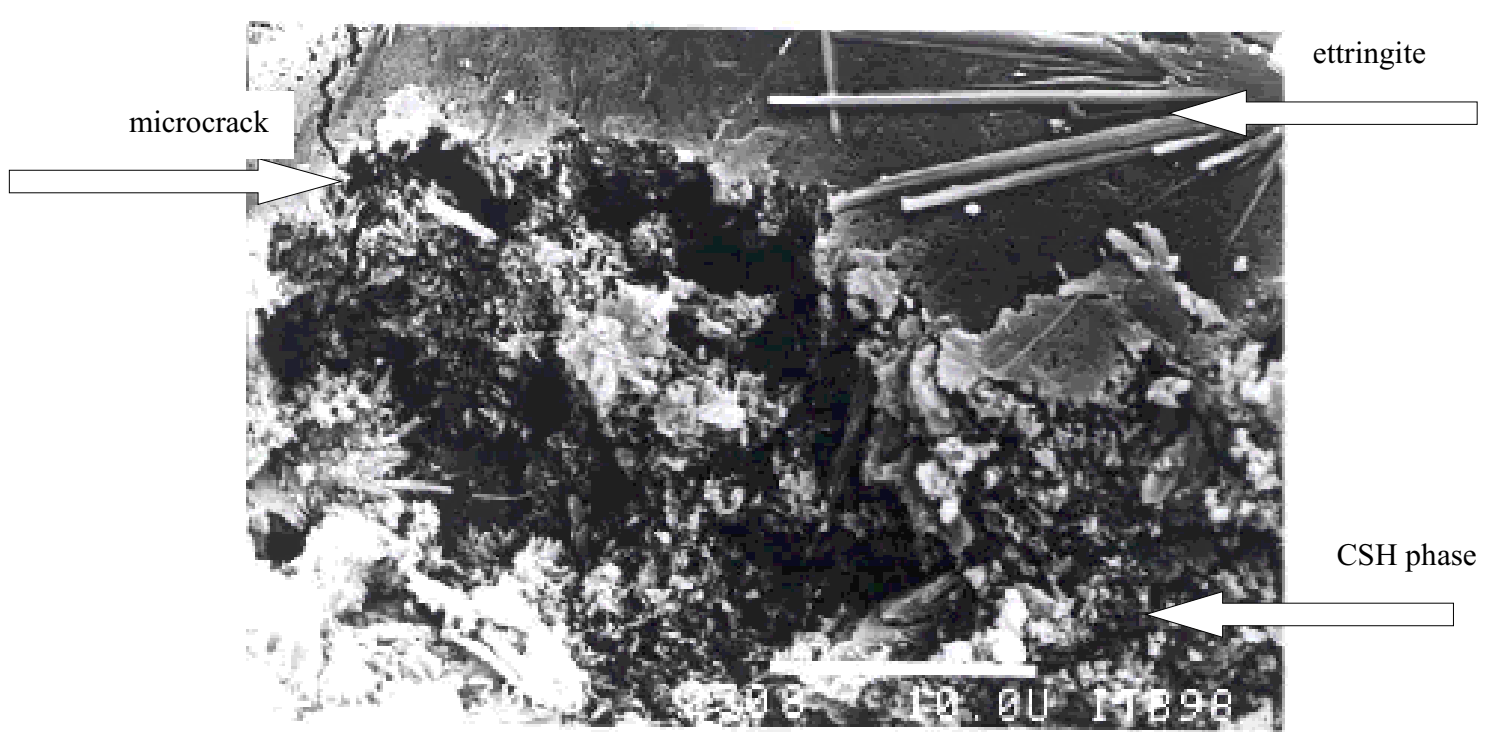

Fig 5. Fraction of concrete after 75 cycles; SEM: magnification 3000x

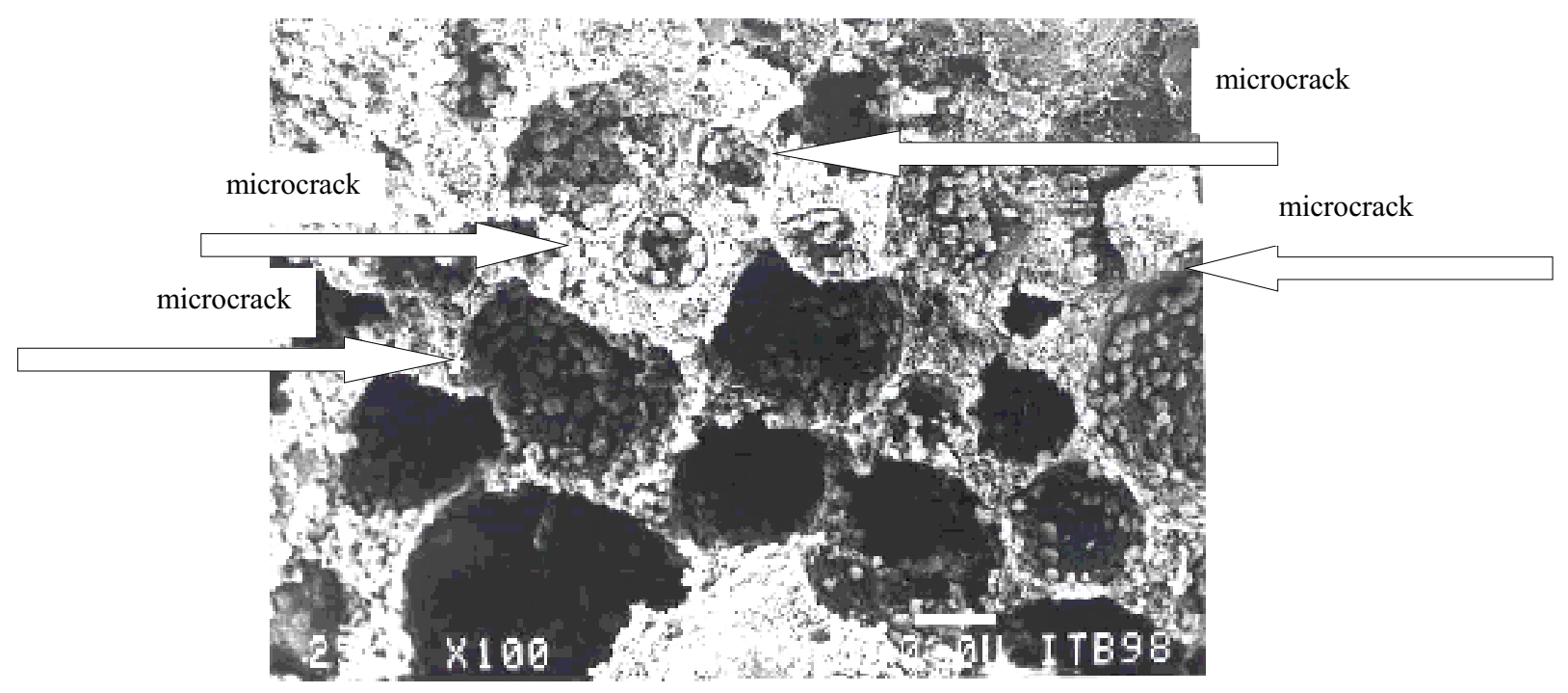

Fig 6. Fraction of concrete after 100 cycles; SEM: magnification 100x

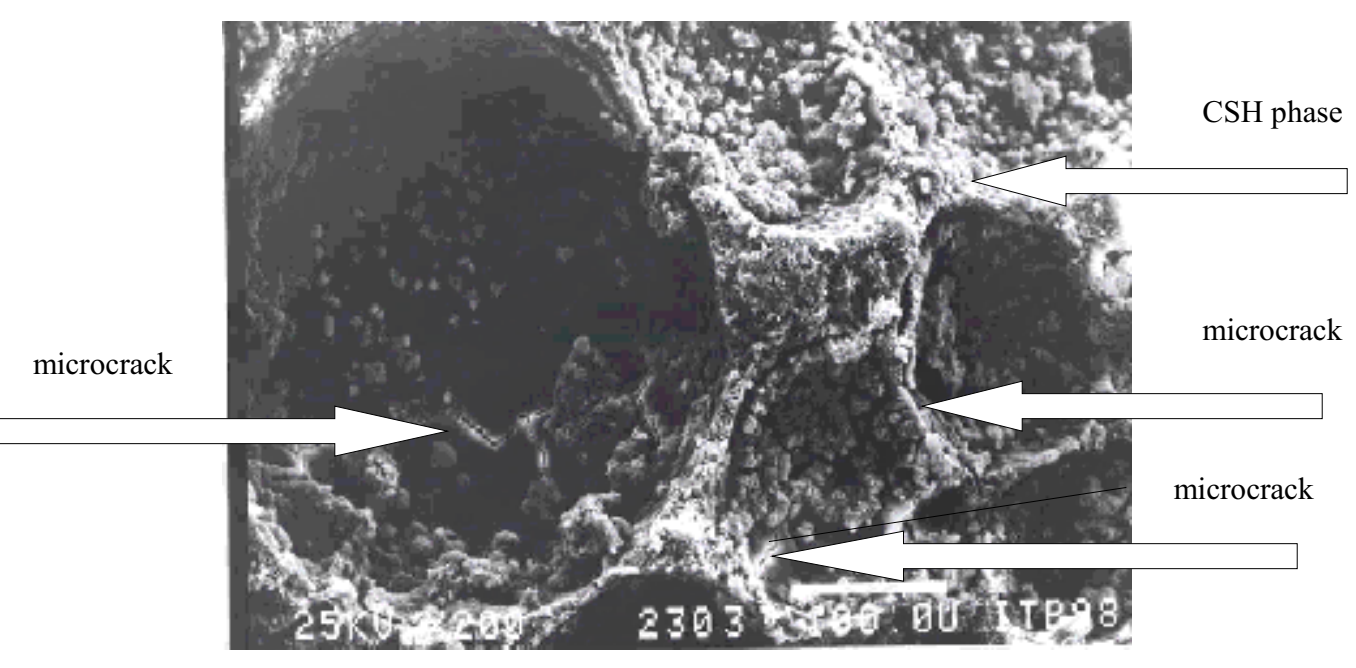

Fig 7. Fraction of concrete after 100 cycles; SEM: magnification 200x 


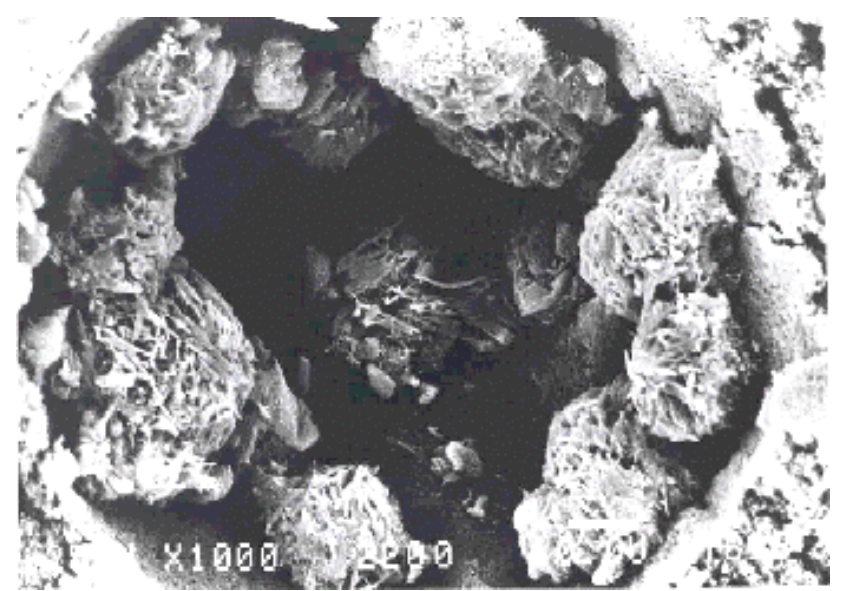

Fig 8. Fraction of concrete after 100 cycles; SEM: magnification $1000 \mathrm{x}$

\subsection{Changes of parameters of porosity}

Examinations of porosity of concrete structure were made on the basis of kinetics of water absorption after $0 ; 25 ; 50 ; 75$ and 100 cycles of freezing and thawing according to the procedure described in GOST 1273078. The method of determining porosity according to kinetics of water absorption is based on the behaviour of liquids (water) in capillary pores. It allows determining total porosity and differential porosity (index of mean radius of capillary pores $-\lambda$, index of homogeneity of capillary pores $-\alpha$ ).

Changes of parameters of concrete porosity take place under the influence of cyclic freezing and thawing. Changes of indexes of mean radius of capillary pores and homogeneity of capillary pores were tested after 0 ; 25; 50; 75 and 100 cycles. The results are presented in Figs 9 and 10.

As it can be seen from Figs 9 and 10 indexes decrease under the influence of the initial cycles of freezing and thawing. Mean radius of capillary pores (1) decreases because of formation of microcracks and partially filling of pores with secondary hydration products. This results in decrease of index of homogeneity of capillary pores. Further freeze-thaw cycles cause formation of more cracks and as a result index of mean pore radius (Fig 9) and index of homogeneity of pores (Fig 10) increase. After 100 cycles parameters of concrete porosity $(1, a)$ returned to the initial values (before cycles).

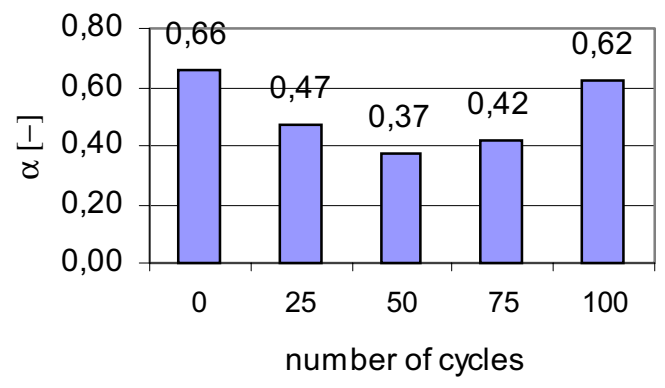

Fig 9. Index of mean radius of capillary pores $(\lambda)$; $\mathrm{W} / \mathrm{C}=0,65$

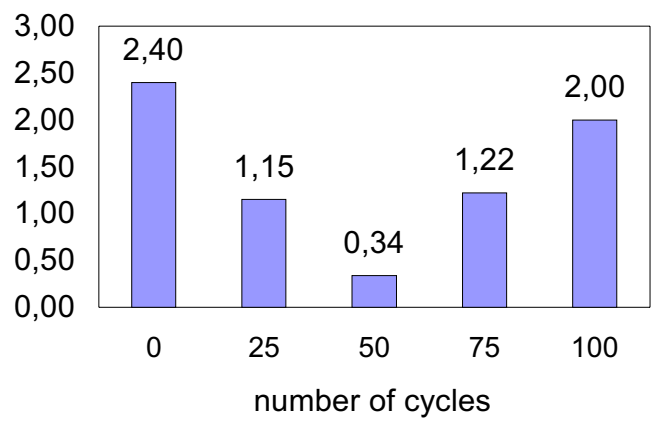

Fig 10. Index of homogeneity of capillary pores $(\alpha)$; $\mathrm{W} / \mathrm{C}=0,65$

\subsection{Thermal analysis of cement stone}

The compositions of selected cement stones separated from concrete specimens determined on the basis of thermal analysis (DTG, DTA and TG) are given in Table 2.

On the basis of test results, it can be stated that quantity phase composition and structure of concrete specimens differ depending on the number of cycles. The content of water chemically bounded in products of hydration is significantly higher in specimens after 100 cycles compared with the control specimens. It is accompanied by the presence of high amount of well crystallised ettringite crystals. Content of calcium hydroxide also increases after 75 and 100 cycles compared with concrete specimens after 0 and 25 cycles. These observations confirm the hypothesis of secondary cement hydration under influence of cyclic freezing and thawing.

Table 2. Composition of hardened cement paste separated from concrete specimens

\begin{tabular}{|c|c|c|c|c|c|c|}
\hline \multirow{3}{*}{ No } & \multirow{3}{*}{ Type of specimen } & \multicolumn{5}{|c|}{ Content of selected components, $\%$ by weight } \\
\hline & & \multicolumn{3}{|c|}{$\begin{array}{l}\text { Water chemically bounded in the temperature range } \\
\qquad 20 \div 5400^{\circ} \mathrm{C}\end{array}$} & \multirow[t]{2}{*}{$\begin{array}{c}\text { Calcium } \\
\text { hydroxide }\end{array}$} & \multirow[t]{2}{*}{$\begin{array}{l}\text { Weight loss } \\
20 \div 1000{ }^{\circ} \mathrm{C}\end{array}$} \\
\hline & & $20 \div 480{ }^{\circ} \mathrm{C}$ & $480 \div 540{ }^{\circ} \mathrm{C}$ & $\Sigma$ & & \\
\hline 1. & 0 cycle & 9,7 & 1,6 & 11,3 & 6,6 & 30,4 \\
\hline 2. & 25 cycles & 9,3 & 1,6 & 10,9 & 6,6 & 29,7 \\
\hline 3. & 75 cycles & 9,2 & 2,3 & 11,5 & 9,5 & 29,3 \\
\hline 4. & 100 cycles & 11,0 & 2,0 & 13,0 & 8,2 & 29,2 \\
\hline
\end{tabular}


Experimental results (structural examinations in SEM, examinations of changes of capillary porosity parameters and the results of thermal analysis) make it possible to describe the phenomena occurring in concrete subjected to cyclic freezing and thawing.

\section{Conclusions}

Cycles of freezing and thawing cause microcracks in hardened cement paste which enable access of water to relicts of unhydrated cement. Then secondary hydration of cement takes place and pores are filled with products of hydration (ettringite and calcium hydroxide first of all). The phenomenon is repeated and continuous changes in porosity structure take place until concrete destruction. Tightening of concrete structure as a result of secondary hydration of unhydrated cement after cycles of freezing and thawing can cause at the beginning increase of compressive strength until irreversible changes take place. Taking into consideration significance of changes of concrete porosity structure under frost influence a trial to develop a method of forecasting freeze resistance on the basis of intensity (speed) of selected porosity parameters changes after initial cycles of freezing and thawing can be undertaken.

The study was supported by State Committee for Scientific Research; project number S/IIB/1/02.

\section{References}

1. Gortchakov, G.; Lifanov, J.; Ivanov, V.; Jurczenko, E. Evaluation of capillary-porous concrete structure. Concrete and Reinforced Concrete (Бетон и железобетон), No 5/1981, Moscow, p. 11-12 (in Russian).

2. Kucharska, L.; Moczko, M.; Mierzejewska, O. Evaluation of concrete freeze resistance on the basis of $R_{c}$ changes connected with transformation of water into ice (Ocena odpornosci mrozowej betonu na podstawie zmian $\mathrm{R}_{\mathrm{c}}$ zwiazanych z przejsciem wody w lod). In: Proceedings of XLVI Scientific Conference KILiW PAN and KN PZITB, Krynica Poland, 2000, p. 215-221 (in Polish).

3. Rusin, Z. Evaluation of aggregate usefulness into freeze resistant concretes (Ocena przydatnosci kruszywa do betonow mrozoodpornych). Archive of Civil Engineering, Vol XXXIV, Z 1/1988, Warsaw, p. 123-139 (in Polish).
4. Sheikin, A. E. About connection between freeze resistance criteria and real concrete freeze resistance. Concrete and Reinforced Concrete (Бетон и железобетон), № 1/1981, Moscow, p. 19-20 (in Russian).

5. Sajna, A. Influence of Porosity on the Freeze-Thaw Salt Resistance of High Performance Mortar. In: Proceedings of the International Congress "Challenges of Concrete Construction". Vol "Concrete for Extreme Conditions", Thomas Telford Publishing, London, 2002, p. 457-466.

6. Grodzicka, A.; Malolepszy, J. The Influence of HPC Microstructure on the Frost Resistance. In: Proceedings of the $6^{\text {th }}$ International Symposium on Utilization of High Strength/High Performance Concrete. Vol 2, Leipzig, 2002, p. 961-975.

7. Palecki, S.; Setzer, M. J. Durability of High Performance Concrete under Frost Attack. In: Proceedings of the $6^{\text {th }}$ International Symposium on Utilization of High Strength/ High Performance Concrete. Vol 2, Leipzig, 2002, p. 12351246.

8. Gagne, R.; Popic, A.; Pigeon, M. Effects of Water Absorption on Performance of Concretes Subjected to Accelerated Freezing-and-Thawing Tests. ACI Material Journal, 2003, p. 286-293.

9. Powers, T. C. A Working Hypothesis for Further Studies of Frost Resistance of Concrete. ACI Journal Proceedings, Vol 41(4), p. 245-272.

10. Fagerlund, G. Internal Frost Attack - State of the Art. In: Proceedings of RILEM Workshop "Frost Resistance of Concrete”. E\&FN Spon, London, 1997, p. 321-338.

11. Lelusz, M.; Bołtryk, M. Correlation between changes of porosity structure after initial cycles of freezing and thawing and concrete freeze resistance. Scientific Bulletin of Bialystok Technical University (Korelacja pomiędzy zmianą struktury porowatości po wstępnych cyklach zamrażania i rozmrażania betonu a jego mrozoodpornościa). Civil Engineering, No 21, 2001, p. 21-35 (in Polish).

12. Lelusz, M. Analysis of methods for determining the concrete freeze resistance. Scientific Bulletin of Bialystok Technical University (Analiza metod określania mrozoodporności betonu). Civil Engineering, No 22, p. 141-155 (in Polish).

13. Lelusz, M. Study of porosity structure of cement concrete in the aspect of its freeze resistance (Studium struktury porowatości betonów cementowych $\mathrm{w}$ aspekcie ich mrozoodporności). PhD thesis of Bialystok Technical University, Bialystok, 2001 (in Polish).

14. Polish Standard PN-88/B-06250 Ordinary Concrete (Beton zwykły). 